\title{
Ownership Structure and Risk Taking of Malaysian Commercial Banks: The Moderating Effects of Capital Adequacy Ratio
}

\author{
Nasyra Ab. Jamil \\ Graduate School of Business, Universiti Kebangsaan Malaysia, Selangor \\ Email: nasyee_3180@yahoo.com \\ Rasidah Mohd. Said \\ Graduate School of Business, Universiti Kebangsaan Malaysia, Selangor \\ Email: rasidah@ukm.edu.my
}

\section{Fauzias Mat Nor}

Faculty of Economics and Muamalat, Universiti Sains Islam Malaysia, Negeri Sembilan Email: fauzias@usim.edu.my

\section{Doi:10.5901/mjss.2015.v6n6s4p139}

\begin{abstract}
In this research, the direct impact of the three ownership structure (government, institutional and family) on bank risk takings measured by Z-Score is to be investigated. This is based on the Z-Score formulation that is used is based on the context that fits for Malaysia as one of the emerging markets. This research also investigates the impact of the ownership structure with capital adequacy ratio as the moderating element towards bank risk taking as measured by Z-Score, along with the five control variables. Data from eight large domestically-owned commercial banks in Malaysia for the period that runs from 2000 to 2012 are used in this research. Multiple regression and hierarchical moderated multiple regression results suggest that the three ownership structures employed in this study do not have any significant relationship on the risk measure in the direct relationship model. However, the results for the model where capital adequacy is included as a moderating factor show a significant relationship link between ownership structure and bank risk taking behaviour. The interaction between the family ownership and capital adequacy are also found to be significant towards risk taking.
\end{abstract}

Keywords: Ownership structure, risk taking, banking, Z-Score, capital adequacy ratio.

\section{Introduction}

From the corporate governance literature it shows that ownership is important and that it is helpful to view the issue in twofold; the context of the principal-agent framework and public choice theory (Altunbas et al., 2001). However, its prime emphasis is basically on non-financial firms, although literature has provided considerable understanding of the effects of ownership.Agency problem between these two entities in the firm are resulted due to the separation of owners (financial provider) from decision maker (manager). The agency problem arises when shareholders yearn for capital return while the decision maker may misappropriate the shareholders' investment. In addition, according to Williams and Nguyen (2005), agency problem is considered the basis of ineffectiveness since it expresses why environmental forces which effect the reactions and effort of management that may fail to pressure the best effort from managers.

The principal-agent problems in banks as per Levine (2004) may raise the issues attributable to what is the most appropriate governance structure for banks. Several aspects as per Williams and Nguyen (2005) that contribute towards the complex issues of bank governance are namely the distinction of bank principles and management, the imperviousness of bank assets, the level of market growth, and the established environment which conditions the total efficiency of financial markets (Williams \& Nguyen, 2005). The argument raised by lannotta et al. (2007) that the dimension of a firm's ownership structure can be defined along two main extents. Initially, refers to the amount of ownership concentration; firms may vary since their ownership is more or less dispersed. Secondly, with the assumption of the same amount of concentration this refers to the nature of the shareholders. Besides, any two firms may vary if the government holds a widely held stake in one of them, which is likewise a stock firm with dispersed ownership, is unlike 
from a mutual firm.

Bank stability has been yet again the top most agenda for the policy makers' agenda across advanced developing countries. According to Beck et al. (2009), the concern has been since the beginning of the 1997-1998 Asian financial crisis, and for the past few years there has been numerous debates around the world on to the stability of banks of different sizes and ownership.Malaysia has experienced two financial crisis namely; Asian Financial Crisis in 1997-1998 and the Global Financial Crisis in 2008-2009 for the past two decades. The 1997/1998 Asian Financial Crisis has been found to be more severe and have left a bigger impact to Malaysia banking industry as compared to the 2008-2009 Global Financial Crisis. The occurrence of the banking crisis is due to the banking fragility, whereby crises are less likely in economies with more concentrated banking systems (Beck et al., 2003). This is due to the profits enhanced by the concentrated banking systems do resulted lower bank fragility. The same issue also has been discussed in (Beck et al., 2006). The stability of a bank is reflected by the degree of the risk taking of the bank.

This research aims to investigate the ownership structure as a mechanism for analysing the determinants of Malaysian bank risk taking. Besides, the main motivating factor of this study is the effect of the 1997/1998 economic crisis. In addition, prior to the situation will be more severe towards bank with poor bank governance if compared to of non-bank firms (Pathan, 2009). Moreover, the bank failures have even more major outlays due to the poor bank governance. Besides, banks which are also considered unique economic units because of their distinguishing roles in financial intermediation, in payment system, liquidity, information and maturity and denomination transformation. In line to this, as suggested by Ahn and Choi (2009) banks are also important as they provide critical monitoring roles in the governance of their borrowers such as reducing borrowers' earnings management behaviour.

The importance of studying bank risk-taking today is far more important than ever before due to the constant attempt of legislation revision as pointed by (Pathan, 2009). All the attempts by the policy makers is to facilitate a better monitoring of the bank activities which includes the bank risk taking behaviour. Besides, the financial shocks in the US such as the sub-prime mortgage crisis in August 2007 due to the irresponsible risk-taking by the financial institutions, do initiate the economy at risk. It is crucial to study on bank risk taking due to the prior results.

This study also attempts to investigate the importance of capital adequacy ratio (CAR) as a moderating factor between the ownership structures with the bank risk takings. Capital adequacy ratio (CAR) is the ratio of a bank's capital to its risk. The remainder of this paper is organized as follows. Section 2 presents an overview of the literature on bank ownership and risk taking. Section 3 describes the data and methods employed, Section 4 discusses the results, and finally Section 5 concludes the findings.

\section{Literature Review and Hypotheses Development}

The main role of the banking system in Malaysia is as the primary mobiliser of funds and also the main source of financing that supports the economic activities in Malaysia. The banking system comprises of commercial banks, investment banks and Islamic banks. The focus in this study is on the eight domestically-owned commercial banks in Malaysia. This is due to the importance of commercial banks as the largest group and most significant providers of funds in the banking system. In addition, commercial banks have the largest share of the market. The classifications of the three main group of the eight commercial banks are as follow; i) Family Owned Banks which comprises of AMMB, HLB, Public Bank and RHB meanwhile, ii) Government Owned Banks consists of Affin, CIMB and Maybank and finally, iii) Alliance Bank Berhad is classified as Corporate Owned Banks.

A sudden decision has encouraged the Malaysia government for a bank merger programme in 1999 due to the worsening situation that have been prompted in some of the banking institutions in the early 1998 in order to consolidate the banking industry as some banking institutions faced difficulties due to their substantial losses and the increase of NPL ratios (Lum \& Koh, 2007).

In July 1999, a robust bank merger programme was initiated by the government in order to restructure all domestic banking institutions into six banking groups as per Lum and Koh (2007) from a total of 77 domestic banking institutions. There were ten leading anchor banks according to the Bank Negara Malaysia Annual Report 2001, following the consolidation programme, namely; Affin Bank Group, Alliance Bank Group, Arab Malaysia Bank Group, BumiputraCommerce Bank Group, EON Bank Group, Hong Leong Bank Group, Malaysian Banking Group, Public Bank Group, RHB Bank Group and Southern Bank Group. The changes in the composition of the ownership structure in the merged banking groups and the market structure of these banks are the consequences due to the consolidation of these banking institutions.

The proper management of risk is through good corporate governance mechanisms which provide a framework of disclosure that allows the market to discern the risk choices of the banking institutions. In order to be effective, it must 
entail greater transparency and market discipline (Lum \& Koh, 2007). The changes in the ownership structure have been an important feature of the evolution for the Malaysian banking sector. The bank ownership structure implies a high concentration of shareholding by ownership types in Malaysia. BAFIA was a clear and robust regulatory response to the crisis of the mid-1980s, which came into force on October 1, 1989.

All banks are required to institutionalize their shareholding structure by restricting ownership in a bank by restricting the limit of equity ownership by individual companies in bank to no more than 20 per cent as per the Banking act of 1973 according to Section 46 of BAFIA 1989. On the other hand, the equity owned by family-owned company or an individual is restricted up to 10 per cent. However, even though the consolidated programme have resulted in larger and better capitalized domestic banking institutions, it does seems to have any significant effect on the composition of ownership structure in the banking industry.

The nature of the shareholding does influence the difference of agency problems and the risk-taking behaviour as referred to the theoretical and empirical literature. The conflict of interest between managers and shareholders is the identified issue raised by Jensen and Meckling (1976). In line to this, the theory raised by (Galai \& Masulis, 1976; Jensen \& Meckling, 1976; Demsetz \& Lehn, 1985; Esty, 1998) point out that shareholders with a varied portfolio are interested to take more risk for a greater expected return whereas managers take not as much of risk to keep their position and individual welfares and to preserve their attained human capital.

Saunders et al. (1990) finds to be the first to test empirically and relationship between banks' ownership structure and their risk taking incentives. Moreover, from the findings also revealed that the banks controlled by shareholders tend to take more risk compared to banks controlled by managers. Based on these findings it motivates to undergo for this research.

It predicts that banks with large dominating shareholders, in other words, with easy control over management, tend to take more aggressive risks than managers who dominated banks with small disperse shareholdings based on theory of risk taking. Besides, prior studies by Ciancanelli \& Gonzalez, 2000; lannotta et al., 2007; John et al., 2008) in the case of banking found that the existence of large shareholders increases bank risk taking.

The level of risks in banks which refer to bank risk taking is measured by insolvency risk (Barry et al., 2011). Bank insolvency problems reveal the degree of exposure to losses or failures which will reduce bank capital reserves that could be used to offset adverse shocks. Bank insolvency risk indicates the banks' distance from failure and is measured using Z-Score. A lower (negative) Z-Score indicates a riskier bank, whereas a higher (positive) Z-Score implies a more stable or the bank is safer. Banks with large dominating shareholders take larger risks than manager-dominated banks with small shareholdings as predicted by (Saunders et al., 1990 ; Laeven \& Levine, 2006).

There are mixed results found on the empirical studies on the effect of ownership on bank risk takings. Ownership concentration positively affects bank's risk taking (Laeven \& Levine, 2009). Besides, banks with concentration ownership tend to have better loan quality, lower asset risk and lower insolvency risk (lannotta et al., 2007). However, Shehzad et al. (2010) on the other hand, suggest that in order for the result to be different, is by a higher levels of ownership concentration with capital adequacy ratio as the proxies for risk. As the result, with the capital adequacy ratio as the proxy of the bank risk, the effect of ownership concentration is positive and in a better risk-weighted capitalization.

\subsection{The relationship between bank ownership and risk}

High concentration ownership in small commercial bank tends to lead to a greater increase in risk-taking as per (GarciaMarco \& Robles-Fernandez, 2008). The situation implicitly is due to higher shareholder concentration that appear linked to a stricter control over managers. This is appearing to be clear evidence for the moral hazard problem which is the increase in risk taking in this kind of institutions. The diversified owners have stronger incentives to increase risk than non-shareholding managers.according to (Laeven \& Levine, 2009). As the result, for banks with powerful and yet diversified owners tend to be riskier than widely held banks.

The diverse levels of risk and profitability are due to the implication of the different ownership structures (Barry et al., 2009).The ownership structure discussed by Barry et al. (2009) consists of government, bank, Financial Company, Mutual and Pension Fund, Nominees, Trust or Trustees, Insurance Company, Individuals and Families. In addition, Barry et al. (2009), banks with different ownership structures tend to have different attitude toward risk taking behaviour. This situation is subject to the different ownership structure in the bank whereby the levels of the risk taking behaviour varies whether they are more or less risky. A higher ownership concentration is associated with lower insolvency risk. Thus, this study proposes the ownership structure to be positively associated with risk (lannotta et al., 2007).

H1: There is positive relationship between ownership structure and risk 


\subsection{The impact of ownership structure on risk with CAR}

Since the response of choice by a non-risk averse will be towards a riskier asset, the distribution of risk aversion across banks is due to the effect of capital requirements on the overall banking system (Naceur \& Kandil, 2009). The potency of more capital at risk through capital requirement enables to internalize the efficiency of investing in high risk assets. The situation will also reduce the capitalized value of expected future profits which is referring to the reduction of the banks' franchise values.

The banks' capital ratio decisions are significantly affected by the capital requirements (Naceur \& Kandil 2009). Besides, the regulatory pressure did positively affect their chosen risk levels, although did not induce banks to increase their capital requirement. According to Shehzad et al. (2010), the capital adequacy ratio positively affected by ownership concentration, and as the result ownership concentration reduces the bank riskiness and this can be measured by ZScore. On the other hand, ownership structure is associated with higher risk is also associated with higher returns (Dolde \& Knopf, 2006).

Ciancanelli and Reyes-Gonzalez (2000) argued that the expropriation problems between shareholders and bank creditors are able to be evaded by capital requirements. The situation is since capital requirement reduce incentives for high risk taking in banking as shareholders are enforced to absorb a greater part of the losses (La Porta et al., (1999); Rime 2001). In supporting the findings, Konishi and Yasuda (2004) found that the implementation of high capital requirement reduced bank risk. This indicates and suggests a negative significant relationship between high capital requirement and bank risk taking. Besides, from the findings it suggests that the implementation of high capital requirement is important in reducing bank risk.

According to Laeven and Levine (2009), the ownership stakes to consider consists of ten per cent and twenty per cent with the Z-Score as the bank risks. However, on the other hand, Shehzad et al. (2010), suggest that in order for the result to be different, is by a higher levels of ownership concentration with capital adequacy ratio as the proxies for risk. As the consequence, the effect of ownership concentration is positive and in a better risk-weighted capitalization with the capital adequacy ratio as the proxy of the bank risk. Based on these prior studies, the current study predicts positive moderation association by capital adequacy ratio between ownership structure and risk.

H2: CAR positively intervene the relationship between ownership structure and risk

\section{Data and Methodology}

The data used in this study consist of annual ownership and financial data for the eight listed commercial banks in Malaysia during the years 2000-2012. The commercial banks included in the sample are AMMB, HLB, Public Bank RHB, Affin, CIMB, Maybank and Alliance Bank. The data are gained from annual reports of the banks, Thomson Financial Datastream data services and Bureau Van Dijk Bankscope.

Usable data for analysis begins from 2000-2012 due to the bank merger and acquisition process completed by 2001. Thus, in order to test both of the models in this research; a balanced panel of data is constructed by collecting yearly data from 2000 until 2012 of eight large domestically-owned commercial banks in Malaysia which consists of 104 observations. Bank risk takings are measured by Z-score and it is as presented below:

Z-SCORE $=3.25+6.56$ (Working Capital / Total Asset) +3.26 (Retained Earnings /

Total Asset) +6.72 (Operating Income / Total Asset) +1.05 (Equity/Total Asset) ${ }^{1}$

Ownership-specific determinants of risk taking behaviour are government ownership, institutional ownership and family ownership are employed in this study. The ownership structure is based on the total accumulation percentage of top 30 shareholders which are gained from the annual reports of the eight banks from 2000 to 2012.

In addition, bank size (BNKSIZE), leverage (LVRG), loan quality (LOANQ), deviation from traditional banking activities (DEVTBA) and management efficiency (MGMTEFF) are employed as control variables. Finally, capital adequacy ratio (CAR) is included as the moderating variable.

The findings by Demsetz and Lehn (1985) agree with the norm of including variable such as bank size as one of the variable in the regression equation. Bank size in this research is measured by the natural logarithm of the total assets of the banks. The situation would be appropriate to take the natural logarithm of total assets in order to reduce the scale effect of numbers and to be consistent with other ratios. Leverage value is represented by the ratio of total debt to common equity (Lee et al., 2008). A higher debt to equity ratio indicates that more creditor financing (bank loans) is used

${ }^{1}$ Bank Negara Malaysia proposed more appropriate measure of Z-Score in the context of emerging market. This formulation is based on Altman (2005). 
than investor financing (shareholders). As for the capital adequacy requirements which were set by central banks are intended to reduce bank insolvency risk is calculated as the ratio of total capital to risk weighted assets of banks.

According to Dugan (2009) it is ideal that the level of loan loss provisioning should be able to reflect the beliefs of banks management on the quality on the loan portfolio that they have. In this research, loan quality (LOANQ) is calculated as the ratio of provision of loan loss to total asset adopted as proposed by (Hassan, 1993). According to DeYoung (2012), traditional banking activities had neither a positive or negative effect on the bank failure. As for the deviation from traditional banking activities (DEVTBA) in this study is measured by the ratio of non-interest income to total asset as proposed by (Madura et al., 1994). The bank is said to be using its assets more effectively, as the greater a bank's earnings in proportion to its assets. As for this research, management efficiency (MGMTEFF) is calculated as the ratio of total earning asset to total asset as prior research by (Angbazo, 1997).

\subsection{The relationship between bank ownership and risk}

Z-Score $=0+{ }_{1}$ GOVOWN $_{\mathrm{it}}+{ }_{2}$ INSTOWN $_{\mathrm{it}}+{ }_{3} \mathrm{FAMOWN}_{\mathrm{it}}+\sum_{j=1}^{7} \gamma_{j} D B_{j}+\mathrm{e}_{\mathrm{it}}$

Where, GOVOWN, INSTOWN and FAMOWN are ownership structure variables, and Z-Score represents risk taking behaviour $D B_{j}$ is a bank dummy variable which is equal to 1 if the bank is Affin Bank and 0 otherwise, 1 if the bank is Alliance Bank and 0 otherwise, and so forth. Besides, Maybank is taken as the reference bank which is selected based on its high total asset for the sample period and $e_{i t}$ is the error term. This model is tested as benchmark for other two models in order to find the relative improvement in model's explanation power.

Hierarchical moderated multiple regression is used to access the effects of a moderating variable which in this research is the capital adequacy ratio (CAR). As for the hierarchical moderated multiple regression, it is required to enter the three ownership structure variables, the control variables and the moderating variable on the first step and then the interaction terms along with the former variables in the second step. From the above discussions, the models are examined as per in Equation (2) and (3).

\subsection{The impact of ownership structure on risk with CAR}

Z-Score $={ }_{0}+{ }_{1}$ GOVOWN $_{i t}+{ }_{2}$ INSTOWN $_{i t}+{ }_{3}$ FAMOWN $_{i t}+{ }_{4} \mathrm{CAR}_{\text {it }}+{ }_{5} \mathrm{BNKSIZE}_{i t}+{ }_{6} \mathrm{LVRG}_{\text {it }}+{ }_{7} \mathrm{LOANQ}_{\text {it }}+{ }_{8} \mathrm{DEVTBA}_{\text {it }}$ $+{ }_{9}$ MGMTEFF $_{\text {it }}+\sum_{j=1}^{7} \gamma_{j} D B_{j}+\mathrm{e}_{\mathrm{it}}$

In order to extract the important of CAR, we adopt the interaction between CAR and the three ownership structure as a new regressor in the panel regression.

Z-Score $=0+{ }_{1}$ GOVOWN $_{\text {it }}+{ }_{2}$ INSTOWN $_{\text {it }}+{ }_{3}$ FAMOWN $_{\text {it }}+{ }_{4}$ GOVOWN $^{*}$ CAR $_{\text {it }}+{ }_{5}$ INSTOWN $^{*}$ CAR $_{\text {it }}+$ ${ }_{6} \mathrm{FAMOWN}^{*} \mathrm{CAR}_{\mathrm{it}}+{ }_{7} \mathrm{CARR}_{\mathrm{it}}+{ }_{8} \mathrm{BNKSIZE}_{i t}+\mathrm{gLVRG}_{\mathrm{it}}+{ }_{10 \mathrm{LOANQ}}+{ }_{11} \mathrm{DEVTBA}_{i \mathrm{t}}+{ }_{12} \mathrm{MGMTEFF}_{i t}+\sum_{j=1}^{7} \gamma_{j} D B_{j}+$ eit $(3)$

Where, Z-Score is calculated using equation provided earlier, GOVOWN, INSTOWN and FAMOWN are ownership structure variables and (CAR) is the capital adequacy ratio. BNKSIZE, LVRG, LOANQ, DEVTBA and MGMTEFF are the control variables. $D B_{j}$ is a bank dummy variable as defined previously. Finally, as for the second step of the hierarchical regression, represented by Model 3 , the interaction variables between the three independent variables and the moderating variable (CAR) are included in the regression. This model assumes that capital adequacy ratio (CAR) as moderating variable has an impact on the dependent variable; Z-Score, through its interaction with the independent variables.

\section{Empirical Results}

In Table 1 the summary of the sample descriptive statistics of ownership structure variables, risk measure, moderating variable, and control variables for the overall sample for the eight commercial banks are presented. The total number of observations in this study for each variable is 104, which came in the form of a panel data of eight cross sections (i.e. commercial banks) and time series of thirteen years. Panels of data are all balanced with no missing data. As for the ownership structure, INSTOWN has the largest mean with value of 51.85 per cent, followed by GOVOWN (13.69 per cent) and FAMOWN (7.67 per cent).

As for the mean for the moderating variable (CAR) is 14.65 per cent, with maximum of 23.8 per cent and minimum of 11.55 per cent which specifies that are all above the capital requirement of 8 per cent as set by the central bank BNM. The indication that the sample of the banks are stable in term of insolvency risk and are in the range of a safe zone since Z-Score with the mean value of 4.11 and maximum of 4.69. In addition, the minimum Z-Score of 2.68 shows that the 
affected banks are in a range of grey zone. None of the banks in the sample are in the distress zone.

Table 1. Descriptive Statistics for the Variables of the Research.

\begin{tabular}{lcccccc}
\hline & Mean & Median & Max & Min & Std.Dev. & Observ. \\
\hline GOVOWN & 0.1369 & 0.0881 & 0.8166 & 0.0000 & 0.1517 & 104 \\
INSTOWN & 0.5185 & 0.5467 & 0.8838 & 0.0891 & 0.2137 & 104 \\
FAMOWN & 0.0767 & 0.0054 & 0.3364 & 0.0000 & 0.1022 & 104 \\
BNKSIZE & 18.1713 & 18.166 & 20.0171 & 13.969 & 0.8958 & 104 \\
LVRG & 2.1329 & 1.7477 & 8.7467 & 0.2541 & 1.4942 & 104 \\
LOANQ & 0.0069 & 0.0065 & 0.0307 & -0.0009 & 0.0053 & 104 \\
DEVTBA & 0.0097 & 0.0089 & 0.0443 & 0.0011 & 0.0049 & 104 \\
MGMTEFF & 0.0086 & 0.0095 & 0.0162 & -0.0211 & 0.0052 & 104 \\
CAR & 0.1465 & 0.1449 & 0.2380 & 0.1155 & 0.0207 & 104 \\
ZSCORE & 4.1099 & 4.137 & 4.6848 & 2.6792 & 0.3066 & 104 \\
\hline
\end{tabular}

Results of the regression analysis on Model 1, Model 2 and Model 3 are presented in Table 3.The F-statistics of these three models suggests that these models are statistically significant. For Equation 1, the result shows that none of the ownership structure; government ownership (GOVOWN), institutional ownership (INSTOWN) and family ownership (FAMOWN) has significant impact on the Z-Score of these eight large domestically-owned commercial banks. In addition, the results also shows that only AMMB and HLB are statistically significant different from the benchmark bank with respect to the risk taking level.

From Table 2 also showed the correlation coefficients for all the related bank risk takings variables. It shows that MGMTEFF is found to be negatively strong correlated to LOANQ. The rest of the variables are found to be either negative or positive with little or weak correlated to each other.

Table 2. Correlation coefficient for bank risk taking variables

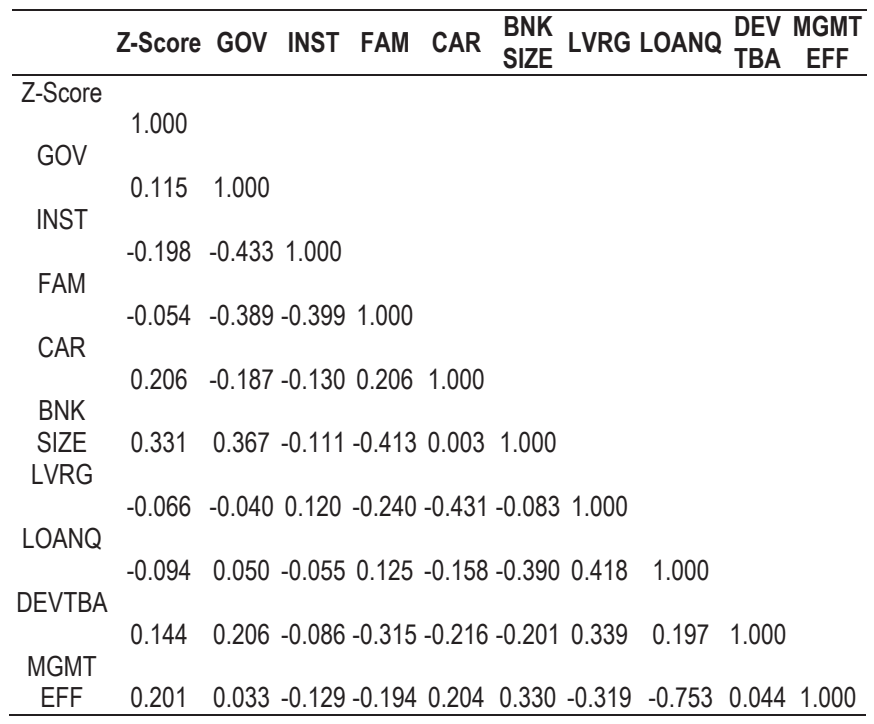

In Equation 2, capital adequacy ratio (CAR) is added as a moderating variable. The results show that CAR is positively significant at 1 per cent level on risk taking of banks. Besides, bank size (BNKSIZE) and leverage (LVRG) are the two control variable that are found to be positively significant and negatively significant, respectively, at 5 per cent level in this model. AMMB retains its significant different from the reference bank, Maybank, in this model. In addition, two other banks, Affin and RHB, are also significantly different from the reference bank.

Equation 3 is to examine the interaction effects of capital adequacy ratio on the relationship between ownership 
structures towards Z-Score. Even though capital adequacy ratio (CAR) is found to be significant as a moderating variable in Model 2, the results from Model 3 shows that capital adequacy ratio (CAR) is found to have a significant effect on the Z-Score only when it interacts with family ownership. Its interaction with the remaining two ownership structures; government and institutional ownership are found to be not significant. As in Model 2, bank size (BNKSIZE) and leverage (LVRG) are the two control variables that are found to be significant in this model and the direction of the relationship is also similar to Model 2. As for the individual banks, Affin, AMMB and RHB are found to be statistically significant different from the reference bank, Maybank.

Table 3. Regression Results for the Models.

\begin{tabular}{|c|c|c|c|}
\hline Variables & Model 1 & Model 2 & Model 3 \\
\hline Intercept & $\begin{array}{c}3.810888 \\
(9.300222)^{* * *}\end{array}$ & $\begin{array}{c}0.819497 \\
(0.598115)\end{array}$ & $\begin{array}{c}3.015788 \\
(1.515243)\end{array}$ \\
\hline GOVOWN & $\begin{array}{c}0.314390 \\
(0.592411)\end{array}$ & $\begin{array}{c}-0.193856 \\
(-0.364779)\end{array}$ & $\begin{array}{c}-2.232549 \\
(-1.055344)\end{array}$ \\
\hline INSTOWN & $\begin{array}{c}0.495012 \\
(0.942776)\end{array}$ & $\begin{array}{c}-0.223298 \\
(-0.410195)\end{array}$ & $\begin{array}{c}-2.344772 \\
(-1.601819)\end{array}$ \\
\hline FAMOWN & $\begin{array}{c}-0.438921 \\
(-0.468405)\end{array}$ & $\begin{array}{c}-0.749845 \\
(-0.744466)\end{array}$ & $\begin{array}{c}-8.504461 \\
(-2.076707)^{\star *}\end{array}$ \\
\hline CAR & & $\begin{array}{c}5.421393 \\
(4.110912)^{\star \star *}\end{array}$ & $\begin{array}{c}-7.362728 \\
(-0.953074)\end{array}$ \\
\hline BNKSIZE & & $\begin{array}{c}0.136964 \\
(2.091497)^{\star \star}\end{array}$ & $\begin{array}{c}0.135293 \\
(1.952590)^{*}\end{array}$ \\
\hline LVRG & & $\begin{array}{c}-0.044935 \\
(-1.997190)^{* *}\end{array}$ & $\begin{array}{c}-0.055547 \\
(-2.401371)^{\star *}\end{array}$ \\
\hline LOANQ & & $\begin{array}{c}1.288104 \\
(0.157981)\end{array}$ & $\begin{array}{c}0.618301 \\
(0.075927)\end{array}$ \\
\hline DEVTBA & & $\begin{array}{c}6.462066 \\
(0.835985)\end{array}$ & $\begin{array}{c}0.247951 \\
(0.029862)\end{array}$ \\
\hline MGMTEFF & & $\begin{array}{c}7.545945 \\
(0.937240)\end{array}$ & $\begin{array}{c}9.472418 \\
(1.172491)\end{array}$ \\
\hline GOVOWN*CAR & & & $\begin{array}{c}11.66694 \\
(0.754808)\end{array}$ \\
\hline INSTOWN*CAR & & & $\begin{array}{c}12.75250 \\
(1.432511)\end{array}$ \\
\hline FAMOWNCAR & & & $\begin{array}{c}49.21807 \\
(1.923510)^{*}\end{array}$ \\
\hline Affin & $\begin{array}{c}0.144374 \\
(0.649763)\end{array}$ & $\begin{array}{c}0.448319 \\
(1.834804)^{*}\end{array}$ & $\begin{array}{c}0.513295 \\
(2.042521)^{* *}\end{array}$ \\
\hline Alliance & $\begin{array}{c}-0.118628 \\
(-0.740881)\end{array}$ & $\begin{array}{c}0.160893 \\
(0.786286)\end{array}$ & $\begin{array}{c}0.170613 \\
(0.794371)\end{array}$ \\
\hline AMMB & $\begin{array}{c}0.215357 \\
(1.857185)^{*}\end{array}$ & $\begin{array}{c}0.520683 \\
(4.463354)^{\star \star *}\end{array}$ & $\begin{array}{c}0.475960 \\
(3.907025)^{\star * *}\end{array}$ \\
\hline CIMB & $\begin{array}{c}0.152514 \\
(1.323862)\end{array}$ & $\begin{array}{c}0.145787 \\
(1.451236)\end{array}$ & $\begin{array}{c}0.141106 \\
(1.411793)\end{array}$ \\
\hline HLB & $\begin{array}{c}-0.446100 \\
(-3.689661)^{\star \star *}\end{array}$ & $\begin{array}{c}-0.224562 \\
(-1.401309)\end{array}$ & $\begin{array}{c}-0.234849 \\
(-1.390363)\end{array}$ \\
\hline PBB & $\begin{array}{c}0.396122 \\
(1.602263)\end{array}$ & $\begin{array}{c}0.050746 \\
(0.218273)\end{array}$ & $\begin{array}{c}-0.041611 \\
(-0.168018)\end{array}$ \\
\hline RHB & $\begin{array}{c}-0.079496 \\
(-0.747794)\end{array}$ & $\begin{array}{c}0.222102 \\
(1.802268)^{*}\end{array}$ & $\begin{array}{c}0.212568 \\
(1.692703)^{*}\end{array}$ \\
\hline Adj. $R^{2}$ & 0.284439 & 0.485061 & 0.490561 \\
\hline F-Statistics & 5.094298 & 7.063976 & 6.220175 \\
\hline $\mathrm{N}$ & 104 & 104 & 104 \\
\hline
\end{tabular}

Note: ${ }^{* * *},{ }^{* *},{ }^{*}$ are significant at 1,5 , and 10 percent significance levels, respectively. 


\section{Conclusion}

The findings of this study will give insight and understanding of the role of ownership structures namely; government ownership, institutional ownership and family ownership in determining the risk taking of commercial banks in Malaysia. This study contributes to the knowledge of the relationship for the three main group of commercial banks (family owned banks, government owned banks and institutional owned banks) which comprise of 8 banks; (Affin, Alliance, AMMB, CIMB, HLB, Maybank, PBB and RHB) towards bank risk taking as measured by the proposed Z-Score measurement. The analysis of the relationship is twofold. First, the direct effect between the three ownership structure and the bank risk taking. Second, is the effect between the three ownership structures towards the bank risk taking along with the moderating variable, control variables and the interaction variables.

The three ownership structures are found not significant towards Z-Score for the direct bank risk taking relationship approach. Thus, this implies that ownership structure namely; government, institutional and family ownership structure, does not have any roles in determining bank risk taking behaviour as proven by prior studies (Garcia-Marco \& RoblesFernandez, 2008 ; Laeven \& Levine, 2009). However, two of the family owned banks namely, AMMB and HLB, are found to be statistically significant different from Maybank as the reference bank in risk taking behaviour as measured by ZScore.

We then examine the implications of capital adequacy ratio (CAR) on bank risk takings. We documents that CAR tends to be positively significant in intervening the bank risk taking. When CAR is included in the empirical analysis, Affin, $\mathrm{AMMB}$ and $\mathrm{RHB}$ are the three banks that are found to be statistically different from the reference bank, Maybank, in their risk taking behaviour. As for the interaction between ownership structure and CAR, CAR accompanied by family ownership influences risk taking of banks. This suggests that the interaction between CAR and family-owned banks play an important role in shaping the risk taking behaviour of banks. Being family-owned banks themselves, RHB and AMMB are found to be statistically significant different from Maybank, which is a government-owned bank, in their risk taking behaviour. However, Affin, which is another government-owned bank, is also found to be statistically significant from Maybank. In conclusion, one can conclude that interaction between CAR and ownership structure is somehow relevant in determining the bank risk taking as measured by Z-Score although with minimal influence.

\section{References}

Ahn, S., \& Choi, W. (2009). The role of bank monitoring in corporate governance: Evidence from borrowers' earnings management behaviour. Journal of Banking \& Finance, 33(2), 425-434.

Altman, E. I. (2005). An emerging market credit scoring system for corporate bonds. Emerging Markets Review, 6(4), 311-323.

Altunbas, Y., Evans, L., \& Molyneux, P. (2001). Bank ownership and efficiency. Journal of Money, Credit and Banking, 33(4), 926-954.

Angbazo, L. (1997). Commercial bank net interest income, default risk, interest-rate risk, and off-balance sheet banking. Journal of Banking \& Finance, 21(1), 55-87.

Barry, T. A., Lepetit, L., \& Tarazi, A . (2009). Bank ownership structure, market discipline and risk: Evidence from a sample of privately owned and publicly held european banks. [Online] Available: http: // papers.ssrn.com /sol3/ papers.cfm?abstract_id= 1331154 (November 1, 2009).

Barry, T. A., Lepetit, L., \& Tarazi, A. (2011). Ownership structure and risk in publicly held and privately owned banks. Journal of Banking \&amp; Finance, 35(5), 1327-1340.

Beck, T., Demirguc-Kunt, A., \& Levine, R. (2003). Bank concentration and crises. National Bureau of Economic Research Working Paper Series No. 9921. [Online] Available: http: // www.nber.org/papers/w9921 (August, 2003).

Beck, T., Demirguc-Kunt, A., \& Levine, R. (2006). Bank concentration, competition, and crises: First results. Journal of Banking \& Finance, 30(5), 1581-1503.

Beck, T., Hesse, H., Kick, T., \& Westernhagen, N. V. (2009). Bank ownership and stability: Evidence from Germany. [Online] Available: https://www.fdic.gov/bank/analytical/cfr/2009/june/CFR_SS_2009_beck.pdf. (April, 2009).

Ciancanelli, P., \& Reyes-Gonzalez, J. A. (2000). Corporate governance in banking: A conceptual framework. [Online] Available: http://papers.ssrn.com/sol3/papers.cfm?abstract_id=253714. (undated).

Demsetz, H., \& Lehn, K. (1985). The structure of corporate ownership: Causes and consequences. Journal of Political Economy, 93(6), 1155-1177.

DeYoung, R. (2012). Nontraditional banking activities and bank failures during the financial crisis. Journal of Financial Intermedian , 22(3), 397-421.

Dolde, W., Knopf, J. (2006). Impact of corporate ownership and governance on risk-taking and returns at thrift institutions. [Online] Available: http://papers.ssrn.com/sol3/papers.cfm?abstract_id=928652.(September, 2006).

Dugan, J. C. (2009). Loan loss provisioning and pro-cyclicality. [Online] Available: http//www.occ.gov/news-issuances/speeches/ 2009/pub-speech-2009-16.pdf. (March 2, 2009).

Esty, B. C. (1998). The impact of contingent liability on commercial bank risk taking. Journal of Financial Economics, 47(2), 189-218. 
Galai, D., \& Masulis, R. W. (1976). The option pricing model and the risk factor of stock. Journal of Financial Economics, 3(1-2), 53-81.

Garcia-Marco, T., \& Robles-Fernandez, M. D. (2008). Risk taking behaviour and ownership in the banking industry: The Spanish evidence. Journal of Economics and Business, 60(4), 332-354.

Hassan, M. K. (1993). Capital market tests of risk exposure of loan sales activities of large U.S. Commercial banks. Quarterly Journal of Business and Economics, 32(1), 27-49.

lannotta, G., Nocera, G., \& Sironi, A. (2007). Ownership structure, risk and performance in the European banking industry. Journal of Banking \&amp; Finance, 31(7), 2127-2149.

Jensen, M. C., \& Meckling, W. H. (1976). Theory of the firm: Managerial behaviour, agency costs and ownership structure. Journal of Financial Economics, 3(4), 305-360.

John, K., Litov, L., \& Yeung, B. (2008). Corporate governance and risk taking. The Journal of Finance, 63(4), 1679-1728.

Konishi, M., \& Yasuda, Y. (2004). Factors affecting bank risk taking: Evidence from Japan. Journal of Banking \& Finance, 28(1), 215232.

La Porta, R., Lopez-De-Silanes, F., \& Shleifer, A. (1999). Corporate ownership around the world. The Journal of Finance, 54(2), 471517.

Laeven, L., \& Levine, R. (2006). Corporate governance, regulation and bank risk taking. [Online] Available: http://citeseerx.ist.psu. edu/viewdoc/download?doi=10.1.1.363.2979\&rep=rep1\&type=pdf. (April 14, 2006).

Laeven, L., \& Levine, R. (2009). Bank governance, regulation and risk taking. Journal of Financial Economics, 93(2), $259-275$.

Lee, K., Lev, B., \& Yeo, G. (2008). Executve pay dispersion, corporate governance, and firm performance. Review of Quantitative Finance and Accounting, 30(3), 315-338.

Levine, R. (2004). The corporate governance of banks: A concise discussion of concepts and evidence. World bank policy research working paper 3404. [Online] Available: http://books.google.com.my/books?id=CPIDv2OzdgC\&dq=The+Corporate+Governance+ of+Banks:+A+Concise+Discussion+of+Concepts+and+Evidence.\&lr=\&source =gbs_navlinks_s. (September, 2004).

Lum, C. S., \& Koh, P. T. N. (2007). Corporate governance of banks in Malaysia. [Online] Available: http://www.ibbm.org.my/pdf/KR BJM003\%20Philip.pdf. (2004).

Madura, J., Martin, A. D., \& Taylor, D. A. (1994). Determinants of implied risk at depository institutions. Applied Financial Economics 4, 363-370.

Naceur, S. B., \& Kandil, M. (2009). The impact of capital requirements on banks' cost of intermediation and performance: The case of Egypt. Journal of Economics and Business, 61(1), 70-89.

Pathan, S. (2009). Strong boards, CEO power and bank risk taking. Journal of Banking \& Finance, 33(7), 1340-1350.

Rahman, N. A. A., Ahmad, N. H., \& Abdullah, N. A. H. (2012). Ownership structure, capital regulation and bank risk taking. Journal of Business and Economics, 3(3), 176-188.

Rime, B. (2001). Capital requirements and bank behaviour : Empirical evidence for Switzerland. Journal of Banking \& Finance, 25(4), 789-805.

Saunders, A., Strock, E., \& Travlos, N. G. (1990). Ownership structure, deregulation, and bank risk taking. The Journal of Finance, 45(2), 643-654.

Shehzad, C. T., de Haan, J., \& Scholtens, B. (2010). The impact of bank ownership concentration on impared loans and capital adequacy. Journal of Banking \&amp; Finance, 34(2), 399-408.

Williams, J., \& Nguyen, N. (2005). Financial liberalisation, crisis, and restructuring: A comparative study of bank performance and bank governance in South East Asia.

Journal of Banking and Finance, 29(8-9 SPEC. ISS.), 2119-2154. 